\title{
РАЗВИТИЕ ФУНКЦИОНАЛЬНОЙ ГРАМОТНОСТИ МЛАДШИХ ШКОЛЬНИКОВ ПУТЁМ ВОВЛЕЧЕНИЯ В ПРОЕКТНУЮ ДЕЯТЕЛЬНОСТЬ
}

\author{
Максимова Елена Викторовна \\ Глушкова Ольга Николаевна \\ МАОУ СОШ № 5
}

\begin{abstract}
Аннотация: В статье рассматривается актуальное направление современного образования - развитие функциональной грамотности, путём вовлечения младших школьников в проектную деятельность. Предлагается циклограмма проектов, разработанная на весь период обучения в начальной школе, а также методическая разработка одного из проектов.
\end{abstract}

Ключевые слова: функциональная грамотность, младший школьник, проектная деятельность, духовно-нравственное развитие.

\section{DEVELOPMENT OF FUNCTIONAL LITERACY OF YOUNGER SCHOOLCHILDREN THROUGH INVOLVEMENT IN PROJECT ACTIVITIES}

\section{Maximova Elena Viktorovna Glushkova Olga Nikolaevna}

\begin{abstract}
The article discusses the current direction of modern education the development of functional literacy by involving younger students in project activities. A cyclogram of projects developed for the entire period of primary school education is proposed, as well as the methodological development of one of the projects.

Key words: functional literacy, junior high school student, project activity, spiritual and moral development.

Главной целью современной системы образования является формирование функционально грамотной личности.

Функционально грамотная личность - это личность, которая способна использовать все постоянно приобретаемые в течение жизни знания, умения и навыки для решения максимально широкого диапазона жизненных задач в
\end{abstract}


различных сферах человеческой деятельности, общения и социальных отношений.

Проще сказать, что функционально грамотная личность - это человек, ориентирующийся в мире и действующий в соответствии с общественными ценностями, ожиданиями и интересами, в частности, умеющий:

- быть самостоятельным в ситуации выбора и принятия решений;

- умеющий отвечать за свои решения;

- способный нести ответственность за себя, своих близких;

- обладающий приемами учения и готовый к постоянной переподготовке;

- для которого поиск решения в нестандартной ситуации - привычное явление;

- легко адаптирующийся в любом социуме и умеющий активно влиять на него;

- понимающий, что жизнь среди людей - это поиск постоянных компромиссов и необходимость искать общие решения;

- хорошо владеющий устной и письменной речью как средствами взаимодействия между людьми;

- современными информационными технологиями;

- обладающий набором компетенций, как ключевых, так и по различным отраслям знаний.

Основы функциональной грамотности закладываются с раннего детства, в том числе и в младшем школьном возрасте. Одним из действенных методов формирующих функциональную грамотность является метод проектов.

Умения, нарабатываемые школьником в процессе проектирования, в отличие от «накопительно-знаниевого» обучения формируют осмысленное исполнение жизненно важных умственных и практических действий. То есть во главу угла ставится сформированность основных типов ключевых компетенций:

- информационной (способы приёма, хранения, оформления и передачи информации);

- проектировочной (способы определения целей, ресурсов их достижения, действий, сроков);

- оценочной (способы сравнения результатов с целями, классификации, абстрагирования, прогнозирования, систематизации, конкретизации); 
- коммуникативной (способы передачи информации и привлечение ресурсов других людей для достижения своих целей).

Участие в различных видах деятельности и освоение их средств дают возможность школьникам приобрести общественно полезный социальный опыт (CO), в ходе которого обучающийся:

- сотрудничает с другими людьми возраста в учебной, игровой и других видах деятельности;

- оценивает собственные действия и действия других людей с точки рения общепринятых норм поведения;

- определяет по вербальному и невербальному поведению состояние других людей и живых существ и адекватно реагировать;

- использует высшие виды игры (игра-драматизация, режиссерская игра, игра по правилам): следует своему замыслу, согласовывает его с партнерами по игре, воплощает в игровом действии; следует правилам; создает и воплощает собственные творческие замыслы;

- проявляет творчествои инициативу в реализации поставленной педагогом задачи, несет ответственность за полученный результат перед собой, своими сверстниками, педагогами и родителями;

- выполняет работы по самообслуживанию и выполняет общественно значимые поручения;

- применяет навыки самоорганизации, самообладания; управляет проявлениями своих эмоций;

- проявляет толерантность к окружающей действительности (уважительное, основанное на искреннем стремлении понять и принять людей другой национальности, культуры, религиозного и бытового мироощущения, отношения; готовность и способность входить с ними в контакт, организовывать продуктивное общение и пр.);

- бережно, с пониманием и любовью относится к флоре и фауне, поддерживает чистоту посещаемых мест;

- предпринимает действия по сохранению и укреплению своего здоровья и безопасности;

- следует ценностям семьи, общества, школы, коллектива.

Ведущие идеи организации проектной деятельности обучающихся:

-в центре деятельности - ученик, педагог обеспечивает содействие развитию его индивидуальности и самореализации; 
- образовательный процесс строится не в логике учебных предметов, а в логике деятельности, имеющей личностный смысл для обучающихся, что повышает их мотивацию;

- каждому предоставляется возможность свободно выбирать (тему, вид, продолжительность, форму проекта). Выбор предполагает ответственность за свою деятельность и ее результат;

- индивидуальный темп работы над проектом обеспечивает выход обучающихся на свой уровень развития;

- проектная деятельность должна быть практически значимой, проект должен иметь свой продукт.

Для получения более высоких показателей развития функциональной грамотности младших школьников целесообразно использовать метод проектов не эпизодически, а системно. Возможно включение в работу близких по тематике проектов, но усложняющихся и дополняющихся в зависимости от возраста учащихся.

Модель организации образовательной среды предполагает включение младших школьников в решение простых проектных задач и участие в проектной деятельности по разным направлениям. Данная модель представлена в циклограмме (табл. 1)

Таблица 1

\begin{tabular}{|c|c|c|c|c|}
\hline \multirow{2}{*}{$\begin{array}{c}\text { Направления } \\
\text { работы }\end{array}$} & \multicolumn{4}{|c|}{ Класс, форма } \\
\hline & 1 & 2 & 3 & 4 \\
\hline \multirow{3}{*}{$\begin{array}{l}\text { Воспитание } \\
\text { гражданствен } \\
\text { ности, } \\
\text { патриотизма, } \\
\text { уважения к } \\
\text { правам, } \\
\text { свободам и } \\
\text { обязанностям } \\
\text { человека }\end{array}$} & $\begin{array}{c}\text { «23 февраля» } \\
\text { праздник настоящих } \\
\text { мужчин (устный } \\
\text { журнал с решением } \\
\text { простой проектной } \\
\text { задачи «Богатырская } \\
\text { застава») }\end{array}$ & $\begin{array}{c}9 \text { мая «Они } \\
\text { сражались за } \\
\text { Родину» (устный } \\
\text { журнал с решением } \\
\text { простой проектной } \\
\text { задачи) }\end{array}$ & $\begin{array}{c}\text { «23 февраля День - } \\
\text { защитников } \\
\text { Отечества» (проект) }\end{array}$ & $\begin{array}{c}\text { Проект «Великая } \\
\text { Отечественная } \\
\text { война» подпроекты: } \\
\text { «Города-герои», } \\
\text { «Памяти народа жить } \\
\text { в веках», } \\
\text { «Пионеры-герои» }\end{array}$ \\
\hline & $\begin{array}{c}\text { «Великие сыны } \\
\text { Отечества» } \\
\text { (проект) }\end{array}$ & $\begin{array}{c}\text { «Великие сыны } \\
\text { Отечества» } \\
\text { (проект) }\end{array}$ & $\begin{array}{c}\text { «Великие сыны } \\
\text { Отечества» } \\
\text { (проект) }\end{array}$ & $\begin{array}{c}\text { «Великие сыны } \\
\text { Отечества» } \\
\text { (проект) }\end{array}$ \\
\hline & $\begin{array}{c}\text { «Мои права и } \\
\text { обязанности» } \\
\text { (устный журнал с } \\
\text { решением простой } \\
\text { проектной задачи) }\end{array}$ & $\begin{array}{c}\text { «Мои права и } \\
\text { обязанности» } \\
\text { (устный журнал с } \\
\text { решением простой } \\
\text { проектной задачи }\end{array}$ & $\begin{array}{c}\text { «Мои права и } \\
\text { обязанности» } \\
\text { (проект) }\end{array}$ & $\begin{array}{c}\text { «Мои права и } \\
\text { обязанности» } \\
\text { (проект) }\end{array}$ \\
\hline
\end{tabular}


Продолжение таблицы 1

\begin{tabular}{|c|c|c|c|c|}
\hline $\begin{array}{c}\text { Воспитание } \\
\text { нравственных } \\
\text { чувств и } \\
\text { этического } \\
\text { сознания } \\
\end{array}$ & $\begin{array}{c}\text { «День мамы» } \\
\text { (устный журнал с } \\
\text { решением простой } \\
\text { проектной задачи) }\end{array}$ & $\begin{array}{c}\text { «День мамы» } \\
\text { (устный журнал с } \\
\text { решением простой } \\
\text { проектной задачи) }\end{array}$ & $\begin{array}{c}\text { «День мамы» } \\
(\text { проект)) }\end{array}$ & $\begin{array}{c}\text { «Валерий Чкалов - } \\
\text { человек легенда» } \\
\text { (устный журнал с } \\
\text { решением простой } \\
\text { проектной задачи) }\end{array}$ \\
\hline $\begin{array}{l}\text { Воспитание } \\
\text { трудолюбия, } \\
\text { творческого } \\
\text { отношения к } \\
\text { учению, } \\
\text { труду, жизни }\end{array}$ & $\begin{array}{c}\text { «Мой алфавит» } \\
\text { (устный журнал с } \\
\text { решением простой } \\
\text { проектной задачи) }\end{array}$ & $\begin{array}{c}\text { Классный час } \\
\text { «Праздник первой } \\
\text { оценки» }\end{array}$ & $\begin{array}{c}\text { «Такие разные } \\
\text { профессии» } \\
\text { (проект) }\end{array}$ & $\begin{array}{c}\text { Общепредметный } \\
\text { итоговый проект } \\
\text { выпускников } \\
\text { начальной школы } \\
\text { (проект) }\end{array}$ \\
\hline \multirow{2}{*}{$\begin{array}{c}\text { Воспитание } \\
\text { ценностного } \\
\text { отношения к } \\
\text { природе, } \\
\text { окружающей } \\
\text { среде } \\
\text { (экологичес- } \\
\text { кое } \\
\text { воспитание) }\end{array}$} & $\begin{array}{c}\text { «Серебристые } \\
\text { снежинки» (устный } \\
\text { журнал с решением } \\
\text { простой проектной } \\
\text { задачи) }\end{array}$ & $\begin{array}{c}\text { «День птиц» } \\
\text { (устный журнал с } \\
\text { решением простой } \\
\text { проектной задачи) }\end{array}$ & $\begin{array}{c}\text { «День Земли» } \\
\text { (проект) }\end{array}$ & $\begin{array}{c}\text { «Времена } \\
\text { года»(проект) }\end{array}$ \\
\hline & $\begin{array}{c}\text { «Сделаем город } \\
\text { чище!» } \\
\text { (проект) }\end{array}$ & $\begin{array}{c}\text { «Сделаем город } \\
\text { чище!» } \\
\text { (проект) }\end{array}$ & $\begin{array}{c}\text { «Сделаем город } \\
\text { чище!» } \\
\text { (проект) }\end{array}$ & $\begin{array}{c}\text { «Сделаем город } \\
\text { чище!» } \\
\text { (проект) }\end{array}$ \\
\hline $\begin{array}{l}\text { Воспитание } \\
\text { ценностного } \\
\text { отношения к } \\
\text { прекрасному, } \\
\text { формирование } \\
\text { представле- } \\
\text { ний об } \\
\text { эстетических } \\
\text { идеалах и } \\
\text { ценностях } \\
\text { (эстетическое } \\
\text { воспитание) }\end{array}$ & $\begin{array}{c}\text { «Пасха красная» } \\
\text { (устный журнал с } \\
\text { решением простой } \\
\text { проектной задачи } \\
\text { «Пасхальная } \\
\text { корзина») }\end{array}$ & $\begin{array}{c}\text { «Сагаалган - } \\
\text { праздник Белого } \\
\text { месяца» (устный } \\
\text { журнал с решением } \\
\text { простой проектной } \\
\text { задачи «Сувенир к } \\
\text { празднику») }\end{array}$ & $\begin{array}{c}\text { «Пасха красная» } \\
\text { (проект «Пасхальное } \\
\text { яйцо») }\end{array}$ & $\begin{array}{c}\text { «Сагаалган - } \\
\text { праздник Белого } \\
\text { месяца» (проект } \\
\text { «Бурятская деревня») }\end{array}$ \\
\hline $\begin{array}{l}\text { Здоровье - } \\
\text { сберегающее } \\
\text { воспитание }\end{array}$ & $\begin{array}{c}\text { « Я здоровье сберегу, } \\
\text { сам себе я помогу!» } \\
\text { (проект) }\end{array}$ & $\begin{array}{c}\text { « Я здоровье сберегу, } \\
\text { сам себе я помогу!» } \\
\text { (проект) }\end{array}$ & $\begin{array}{c}\text { « Я здоровье сберегу, } \\
\text { сам себе я помогу!» } \\
\text { (проект) }\end{array}$ & $\begin{array}{c}\text { « Я здоровье сберегу, } \\
\text { сам себе я помогу!» } \\
\text { (проект) }\end{array}$ \\
\hline
\end{tabular}

На начальном этапе (1-2 класс) целесообразно включать младших школьников в решение простых проектных задач, в 3 и 4 классе в работу над проектами. Метод проектов актуален как в урочной деятельности, так и во внеурочной.

Направления работы нам подсказала концепция духовно-нравственного развития и воспитания личности гражданина России, где чётко определён национальный воспитательный идеал - гражданин России высоконравственный, творческий, компетентный, патриотичный, осознающий ответственность за будущее своей страны, придерживающийся духовных и культурных традиций своей страны. 
Кроме того, в концепции перечислены основные направления духовно-нравственного развития и воспитания учащихся:

- Воспитание гражданственности, патриотизма, уважения к правам, свободам и обязанностям человека;

- Воспитание нравственных чувств и этического сознания;

- Воспитание трудолюбия, творческого отношения к учению, труду, жизни;

- Воспитание ценностного отношения к природе, окружающей среде (экологическое воспитание;

- Воспитание ценностного отношения к прекрасному, формирование представлений об эстетических идеалах и ценностях (эстетическое воспитание).

Таким образом, вовлечение младших школьников в проектную деятельность позволяет реализовывать современные тенденции Российского образования, а именно способствует формированию функциональной грамотности и духовно-нравственному развитию личности.

Работу над проектом продемонстрируем на примере группового долгосрочного проекта «К юбилею великой Победы»

\section{Групповой долгосрочный проект \\ «К юбилею Великой Победы» на параллели 4-х классов}

Цель: воспитание патриотизма, чувства гордости за подвиг нашего народа в Великой Отечественной войне, учить работать в группе - развивать умение сотрудничать, распределять обязанности и выполнять их, воспитание чувства ответственности.

\section{Описание проекта.}

Работа над проектом ведётся в течение 1 учебного года. Проект включает в себя 4 малых проекта. Учащиеся 4-х классов (4a, 46, 4в) делятся на 4 группы (внутри каждого класса 4 группы). Каждая группа проявляет себя в одном из проектов в течении учебного года.

За время работы над одним малым проектом группы встречаются с руководителем 3 раза:

1 раз -получение задание (тему проекта) и распределение обязанностей ;

2 раз -корректировка работы группы;

3 раз - создание продукта ( выпуск стенгазеты, подготовка презентации)

Сроки проведения:

1 проект «Города- герои» (групповой) - ноябрь; 
2 проект «Пионеры - герои» (групповой) - декабрь;

3 проект «Памятники героям» (групповой) - март;

4 проект «Открытка ветерану» (индивидуальный) - май.

Подведением итога по данному долгосрочному проекту будет являться образовательное событие, посвящённое юбилею Великой Победы «Как это было...», в ходе которого пройдет защита проектов.

Распределение обязанностей в ходе работы над проектом представлено в таблицах 2, 3, 4.

1 проект «Города- герои» (групповой)

- Брестская крепость герой. (4 «а» класс)

- Битва за Москву. (4 «б» класс)

- Блокада Ленинграда(4 «в» класс)

Таблица 2

\begin{tabular}{|c|c|c|}
\hline Брестская крепость герой & Битва за Москву & Блокада Ленинграда \\
\hline оформление & оформление & оформление \\
\hline защитники & защитники & Время обороны \\
\hline Время обороны & Время обороны & Стихи \\
\hline Стихи & Стихи & Фотографии иллюстрации \\
\hline Фотографии иллюстрации & Фотографии иллюстрации & .
\end{tabular}

2 проект «Пионеры - герои» (групповой)

Таблица 3

\begin{tabular}{|c|c|c|}
\hline Валя Котик & Зина Портнова & Марат Казей \\
\hline оформление & оформление & оформление \\
\hline подвиг & подвиг & пвиг \\
\hline Стихи $\quad$ по теме & Стихи по теме & поме \\
\hline Фотографии иллюстрации & Фотографии иллюстрации & Фотографии иллюстрации \\
\hline
\end{tabular}

\section{3 проект «Памятники героям» (групповой)}

Таблица 4

\begin{tabular}{|c|c|c|}
\hline$\ldots \ldots$ & $\ldots \ldots$ & $\ldots \ldots$ \\
\hline оформление & оформление & оформление \\
\hline подвиг & подвиг & подвиг \\
\hline Стихи по теме & Стихи по теме & Стихи по теме \\
\hline Фотографии иллюстрации & Фотографии иллюстрации & Фотографии иллюстрации \\
\hline
\end{tabular}

4 проект «Открытка ветерану» (индивидуальный)

Способ изготовления открытки учащиеся выбирают самостоятельно. 


\section{Список литературы}

1. Бритвина Л.Ю. Метод творческих проектов на уроках технологии. // Нач.школа. - 2005. - № 6.

2. Григорьев Д.В. Внеурочная деятельность школьников. (Стандарты нового поколения) - М., 2010.

3. Михеева О.П., Шевцова Н.Г., Зубарева И.В. Организация внеурочной деятельности в начальной школе. Сборник программ. Методическое пособие. - М.: Планета, 2015.

4. Степанов П.В., Степанова И.В. Воспитание и внеурочная деятельность в стандарте начального общего образования. - М.: Центр «педагогический поиск», 2011.

5. Щербакова С.Г. «Организация проектной деятельности в школе: система работы» Волгоград: Учитель, 2008 г. 